\title{
MODERN CONCEPT OF UNDERSTANDING THE HUMAN RIGHT TO LIFE
}

DOI:10.36740/WLek202102131

\author{
Anna V. Dzhuska' ${ }^{1}$, Natalia V. Kaminska² ${ }^{2}$ Zoryana M. Makarukha ${ }^{3}$ \\ 'EDUCATIONAL AND SCIENTIFIC HUMANITARIAN INSTITUTE OF V. I. VERNADSKY TAURIDA NATIONAL UNIVERSITY, KYIV, UKRAINE \\ 2NATIONAL ACADEMY OF INTERNAL AFFAIRS OF UKRAINE, KYIV, UKRAINE \\ ${ }^{3}$ GOVERNMENT OFFICE FOR EUROPEAN AND EURO-ATLANTIC INTEGRATION, KYIV, UKRAINE
}

\begin{abstract}
The aim: The purpose of this article is to expose the essence of the concept of the human right to life, including in the content of this right, the duty of the state to maintain and develop general conditions for a dignified human life.

Materials and methods: The article explores the modern concept of understanding the human right to life. The article analyzes the constitutions, other regulations, as well as the experience of different countries in the world on this issue (in particular, the countries of Western and Eastern Europe, Latin America, USA). The empirical basis of this research consists of two judgments of the Constitutional Court of Ukraine, Resolution of the Plenum of the Supreme Court of Ukraine «On Judicial Practice in Cases of Crimes against the Life and Health of a Person» of February 7, 2003, № 2, and judgments of the European Court of Human Rights (Case of Lambert and others v. France of 5 June 2015, Case Hristozov and others v. Bulgaria of 13 November 2012, Case G. N. and others v. Italy of 01 December 2009) on issues related to the human right to life. The application of methods and techniques of scientific knowledge is conditioned by a systematic approach, which enables them to consider outlined problems in the unity of their social content and legal form. In particular, the formal-logical method, methods of analysis and synthesis, comparative-legal method, formal legal and statistical methods are used.

Conclusions: The modern approach to understanding the human right to life presupposes that it is the state's responsibility to protect that right, to take appropriate measures to remedy the general conditions in society that may endanger life or prevent individuals from living a dignified life.
\end{abstract}

KEY WORDS: human rights, right to life, death penalty, suicide, euthanasia, abortion, medical error, worthy life

Wiad Lek. 2021;74(2):341-350

\section{INTRODUCTION}

Much of the democratic states of the world have enshrined at the constitutional level the provisions guaranteeing everyone the right to life (for example, Article 20 of the Constitution of the Russian Federation, amendment V to the US Constitution, Article 5 of the Constitution of Brazil, Article 31 of the Constitution of Japan, Article 15 of the Constitution of Spain, 2 of Article 2 of the Constitution of Germany, Article 38 of the Constitution of Poland, Article 24 of the Constitution of Moldova, Article 27 of the Constitution of Ukraine, etc.).

The human right to life is a fundamental, inalienable right of everyone, which, unfortunately, is often violated, and we, therefore, consider it worthwhile to pay close attention to it. The relevance of this issue is enhanced by the fact that exploring the right to life, we can distinguish another right the right to a worthy life, which requires scientific analysis. It should be noted that the human right to life has become the subject of many works of scientists, but the mentioned problems do not lose their relevance and need further research.

\section{THE AIM}

The aim of this article is to reveal the essence of the concept of «human right to life», to analyze its constituent elements; to investigate international human rights instruments concerning the right to life, and to consolidate this right in the constitutions of different countries of the world; consider human rights issues (death penalty, suicide, euthanasia, abortion, medical error) in the light of experience from around the world, as well as the concepts of «necessary defense» and «extreme necessity». It also seeks to highlight the possibility of including in the human right to life the duty of the state to maintain and develop general conditions for a worthy human life.

\section{MATERIALS AND METHODS}

The article explores the modern concept of understanding human right to life. The article analyzes the constitutions, other regulations, as well as the experience of different countries in the world on this issue (in particular, the countries of Western and Eastern Europe, Latin America, USA). The empirical basis of this research consists of two judgments of the Constitutional Court of Ukraine, Resolution of the Plenum of the Supreme Court of Ukraine «On Judicial Practice in Cases of Crimes against the Life and Health of a Person» of February 7, 2003, № 2, and judgments of the European Court of Human Rights (Case 
of Lambert and others v. France of 5 June 2015, Case Hristozov and others v. Bulgaria of 13 November 2012, Case G. N. and others v. Italy of 01 December 2009) on issues related to the human right to life.

The methodological basis of the study is the methods and techniques of scientific knowledge. Their application is conditioned by a systematic approach, which enables them to consider outlined problems in the unity of their social content and legal form. In particular, the formal-logical method was applied to analyze the elements of the human right to life, as well as to establish the essence of the concept of the human right to life and other related concepts. Methods of analysis and synthesis have revealed the logical structure of the concept of human rights to life, the construction of definitions and other theoretical constructs, and the comparative-legal method - to compare the laws of different countries of the world concerning the issue of human rights to life. To formulate the concepts of «human right to life», «suicide», «euthanasia», «abortion», etc., a formal legal method was used. The statistical method has helped to investigate statistical information on abortion worldwide.

\section{REVIEW AND DISCUSSION}

The primary in origin and meaning and inalienable human right is its right to life that arises from birth. This right cannot be revoked or restricted by anyone.

It is interesting that in many countries the law provides that the right to a person's life arises from its conception. In particular, in Japan, a person's age is calculated from the time of conception. The term "nasciturus» comes from Latin and means the one who is to be born, a child who is still inside his/her mother's womb. From the moment of conception until his/her birth, a child inside his/her mother's womb undergoes various stages, and nasciturus would be a general term for a child inside his/her mother, until the moment of his/her birth or at least the beginning of childbirth [1]. The nascitrus has a number of personal and property rights, protected mainly by private law.

The right to life is an inalienable, fundamental human right that relates to civil (personal) rights in the system of fundamental rights and freedoms of person and citizen. By the way, this right is a natural human right, it is enshrined in the most important international human rights instruments.

Thus, Article 3 of the Universal Declaration of Human Rights of 10 December 1948 states that everyone has the right to life, liberty, and security of person [2].

Article 6 of the International Covenant on Civil and Political Rights of 16 December 1966 provides that every human being has the inherent right to life. This right shall be protected by law. No one shall be arbitrarily deprived of his life. In countries which have not abolished the death penalty, sentence of death may be imposed only for the most serious crimes in accordance with the law in force at the time of the commission of the crime and not contrary to the provisions of the present Covenant and to the Convention on the Prevention and Punishment of the Crime of Genocide. This penalty can only be carried out pursuant to a final judgment rendered by a competent court. When deprivation of life constitutes the crime of genocide, it is understood that nothing in this article shall authorize any State Party to the present Covenant to derogate in any way from any obligation assumed under the provisions of the Convention on the Prevention and Punishment of the Crime of Genocide. Anyone sentenced to death shall have the right to seek pardon or commutation of the sentence. Amnesty, pardon or commutation of the sentence of death may be granted in all cases. Sentence of death shall not be imposed for crimes committed by persons below eighteen years of age and shall not be carried out on pregnant women. Nothing in this article shall be invoked to delay or to prevent the abolition of capital punishment by any State Party to the present Covenant [3].

Article 2 of the Convention for the Protection of Human Rights and Fundamental Freedoms of 4 November 1950 provides that everyone's right to life shall be protected by law. No one shall be deprived of his life intentionally save in the execution of a sentence of a court following his conviction of a crime for which this penalty is provided by law. Deprivation of life shall not be regarded as inflicted in contravention of this Article when it results from the use of force which is no more than absolutely necessary: (a) in defence of any person from unlawful violence; (b) in order to effect a lawful arrest or to prevent the escape of a person lawfully detained; (c) in action lawfully taken for the purpose of quelling a riot or insurrection [4].

For the first time at the legislative level, the right to life was enshrined in the text of the Declaration of Independence of the United States in 1776.

The provisions of these international legal acts have been reflected in many constitutions of the countries of the world. For example, in Art. 15 of the Spanish Constitution states that «everyone has the right to life, to physical and moral integrity, and no one can, in any case, be subjected to torture or to inhuman or degrading treatment» [5]. Art. 38 of the Constitution of Poland enshrined the provision that the Polish Republic guarantees every person legal protection of life [6]. In Art. 5 of the Brazilian Constitution states that Brazilians and foreign residents have the right to life, liberty, equality, security and property [7]. Amendment $V$ (1791) to the US Constitution provides that no person shall be nor be deprived of life, liberty, or property, without due process of law [8]. Understanding of the right to life under the Constitution of Ukraine is possible only in the context of at least two of its articles -3 and 27, where Article 3 forms the fundamental value approach of the Ukrainian state to a person, his life and health as to the "highest social value» in Ukraine, and in Article 27 sets out the general content of the personal right to life: «Everyone has the inherent right to life. No one can be arbitrarily deprived of his life. It is the duty of the state to protect human life. Everyone has the right to defend his life and the health, life, and health of others against unlawful encroachment» [9]. 
The current understanding of the right to life implies the abolition of the death penalty. According to international experience, the death penalty has not been justified as an effective tool in the fight against crime. This punishment does not apply to crime-deterrents. That is why around 100 countries have abolished the death penalty (Australia, Brazil, almost all European countries). However, in some countries, the death penalty continues to persist (China, Iran, Iraq, Saudi Arabia, North Korea, etc.).

In July 2019, the US Department of Justice decided to return to the death penalty. For the past 16 years, the unofficial moratorium has been at the highest level at the federal level. The last federal government in the United States applied the death penalty in 2003. At the state level, this punishment could continue to be applied. In the United States, the death penalty is administered by administering to prisoners an injection of pentobarbital (a drug that gradually slows down the body, including the nervous system, and eventually leads to death) [10].

Structurally, the right to life can be considered as having three components: 1) the inalienability of the human right to life; 2) prohibition of arbitrary deprivation of life; 3) the right to protect one's life and the lives of others against unlawful encroachment. As noted above, the right of a person to deprive another person's life as a result of the inevitable need to use force in cases determined by law is recognized [11, p. 186].

The inherent right to life belongs to everyone regardless of race, color, political beliefs, citizenship, etc. The inalienability of the right to life should be seen as a consequence of the naturalness of that right. No one, including the Constitution, gives a person the right to live.

To better understand the essence of the human right to life, let us turn to the national judicial practice of Ukraine.

It should be noted that according to the Judgment of the Constitutional Court of Ukraine in the case on the constitutional petition of 51 people's deputies of Ukraine on the constitutionality of the provisions of Articles 24, 58, 59, 60, 93, 190-1 of the Criminal Code of Ukraine in part, which provides for the death penalty as a form of punishment (Death Penalty Case) of 29 December 1999 № 11-rp/1999, there is every reason to believe that the inalienable right of every person to life is inextricably linked with his right to human dignity. As basic human rights, they determine the possibility of exercising all other human rights and freedoms and can be neither restricted nor abolished [12].

It is the duty to protect a person's life and, therefore, to guarantee the right to a life that is constituted, above all, by the state. The state itself assumes certain obligations to protect human life. Such duties should include, first of all, the following: establishing legal (criminal) responsibility for the unlawful encroachment on a person's life and the unlawful deprivation of his or her life; the prohibition to deprive any person of his life arbitrarily; prohibition of extradition of a person to a state in which the death penalty may be applied; a ban on the expulsion of a person to a country where his or her life is threatened; introduction of legal remedies for protection of the right to life, in partic- ular when there is a high likelihood of absolute threat to human life; introducing legal safeguards to protect a person who protects his or her life or health or the lives and health of others from unlawful encroachment [11, p. 186-187].

The Constitutional Court of Ukraine considers that the positive obligation of the state to implement an adequate system of protection of life, health, and human dignity is to ensure effective investigation of the facts of deprivation of life and ill-treatment, including persons in places of imprisonment under state control [13].

There are a number of legal acts in the laws of different countries of the world aimed at ensuring the human right to life. In particular, these are criminal codes (criminal responsibility for intentionally or negligently depriving a person of his or her life; introducing concepts of necessary defense and extreme necessity).

Those States which have ratified the Convention for the Protection of Human Rights and Fundamental Freedoms are not entitled to extradite a person to States in which the death penalty may be applied.

The duty of the state to ensure the right to life and thus to protect the life of a person should be regarded as both its positive and negative constitutional obligation [11, p. 187]. A positive obligation is to oblige state bodies (in particular, the legislature and other state bodies empowered to adopt by-laws) to enforce a constitutional prescription for the creation of legislation that would ensure the right to life. Such activity is absolutely necessary in view of the complexity of this right and the development in the world of ideas about its content. This activity also applies to the full national implementation of acts of dynamic interpretation by the international bodies of ratified international human rights treaties [11, p. 187-188]. The state's negative obligation on the human right to life is the obligation to create the appropriate organizational, personnel, financial and other conditions to ensure the implementation of the relevant legislation. The inability or unwillingness of the state to do so will be indicative of a violation of the constitutionality of the state, for example, a brazen delay in carrying out the necessary investigative measures in a murder case or the refusal of judges to apply the European Court of Human Rights (hereinafter - ECHR) decisions on the protection of the right to life when this is the basis [11, p. 188].

According to the Resolution of the Plenum of the Supreme Court of Ukraine of February 7, 2003, № 2 «On Judicial Practice in Cases of Crimes against the Life and Health of a Person", the courts of Ukraine generally comply with the requirements of the legislation regulates liability for crimes against life and health of a person.

However, there are cases when during the trial of this case categories are allowed violations of both material and procedural law.

The Court ruled that one of the important guarantees of the implementation - the human right to life and health which is proclaimed by articles 3 and 27 of the Constitution of Ukraine, is unconditional fulfillment by courts of requirements of criminal procedure the law on ensuring the rights of victims of these crimes. 
In cases of crimes of this type, the courts are obliged as to establish the guilt of the defendants and assign them the necessary and sufficient to correct them and prevent new crimes of punishment, and take all necessary measures until full reimbursement material and moral damage caused to the victim. According to Part 1 of Art. 64 of the Criminal Code of Ukraine, life imprisonment is appointed only in cases specifically provided for therein Code, and provided that the court does not consider it possible to apply imprisonment for a definite term. The purpose of this punishment must be motivated in the sentence with the obligatory indication of circumstances, which, according to the court, prevent the application of imprisonment on a certain period. If several are found guilty of a crime persons sentenced to life imprisonment shall be sentenced the relevant motives for each of them shall be stated separately [14].

The right to life does not belong to the absolute, that is, there is no absolute, unrestricted prohibition on depriving a person of life. In some cases, a person may be deprived of life because of the inevitable need to use force. But such cases, since they limit human rights, must be determined solely by the laws of the state. In addition, as noted above, international human rights instruments (for example, Art. 2 of the Convention for the Protection of Human Rights and Fundamental Freedoms) refer to cases of the extreme necessity to use force [11, p. 188].

The laws of the states may establish the grounds for the use of coercive measures, in particular, firearms (for example, Art. 17 of the Law of Ukraine «On the National Police»). The ECHR and other international human rights bodies consider proportionality, expediency and absolute necessity as the main criteria in the legal assessment of the use of force, including weapons, in the course of a lawful arrest or the prevention of the escape of a lawfully detained person. Thus, according to the legislation of Ukraine, it is forbidden to use police force, special means and firearms for women with obvious signs of pregnancy, minors, persons with obvious signs of disability or old age, except in cases of armed or group attack, armed resistance to police that threatens the lives and health of others or police officers if it is not possible to repel such an attack or resistance by other means and means. The police are also forbidden to use firearms in places where harm can be caused to other persons, as well as inflammable and explosive places, except in cases of necessity to repel an attack or an extreme necessity (Part 5 of Art. 43, Part 9 of Art. 46 of the Law of Ukraine «On the National Police») [15].

All international legal practice concerning the assessment of the legitimacy of deprivation of life when committing lawful acts to suppress an uprising or rebellion is based on the application of the principle of «absolute necessity» [11, p. 190].

In exploring the human right to life, one cannot escape the contemporary problematic issues associated with this right, such as suicide, euthanasia, and abortion.

Suicide is the deprivation of one's self (without assistance) of one's physical life, which occurs as a result of a voluntary, deliberate decision, or as a result of affect.
Suicide is an extreme form of a wide range of self-destructive behavior. The latter is considered to include various indirect forms of behavior, such as intentional and deliberate harm to life-threatening and threatening, self-harm (some extreme sports, risky behavior). The most dramatic form of suicidal behavior is so-called "prolonged suicide», when a person, taking his own life, decides to «withdraw» people from the environment. Fortunately, these situations are very rare, often the result of extremely severely altered thinking (for example, a mother is convinced of a serious illness of a child, suffering, unhappiness, catastrophe; she believes that death is the best solution and help for him). Fortunately, suicide attempts usually do not end in death. They are an expression of human helplessness to life's problems, a cry for help - often unknown. According to statistics, women are much more likely to attempt suicide, men are more likely to actually save their own lives. The choice of method plays a role here. For example, men in Poland usually try to hang themselves (in the US - they use firearms), while women try to take a large number of drugs. Often, these are sleeping pills and tranquilizers (according to the popular belief that "you can fall asleep after them and not wake up») that are actually relatively toxic. It should be noted that suicide should not be considered a consequence of mental disorders. One can imagine a mentally healthy person committing suicide (for example, for ideological reasons, suicide during the war, after the arrest, fearing that torture will cause others to fall, or the suicide of a person who knows about a terminal illness and wants to avoid suffering, related). In the latter case, the decision on suicide is quite similar to the decision on euthanasia. Of course, a mentally healthy person has the psychological ability to make the decision to end their life at the "optimal» moment for themselves. On the other hand, the vast majority, as many as $80 \%$ of suicide victims, are people with mental disorders [16].

The modern theory of law proceeds from the general recognition of the right of the person to consciously dispose of his own life. In the case of a mental disorder of a person who commits or manifests a real intention to take actions that present an immediate danger to him or others or is unable to satisfy his or her basic needs independently at a level that ensures his or her vital activity, such person may be involuntarily admitted to a psychiatric care facility. It should be noted that driving a person into suicide is a crime (Art. 120 of the Criminal Code of Ukraine, Art. 151 of the Criminal Code of the Republic of Poland, etc.).

Euthanasia (Greek $\varepsilon v$ - good + Greek. Oávatoc - death) should be distinguished from suicide - the artificial deprivation of a person's life in the presence of will on his part by medical means in cases of incurable illness or serious health impairment (fatal injuries, etc.) of that person [11, p. 190]. According to such a criterion, as a method of implementation, euthanasia is divided into an active (positive or «filled syringe method»), that is the use of special means or other actions that result in a quick and painless death, and a passive (negative or «method of the deposited syringe»), which means the abandonment of measures conducive to 
maintaining life, that is the termination of the provision of life-saving medical care that accelerates the ting natural death. According to another criterion, the subject of the expression, euthanasia is divided into voluntary, that is, the use of medicinal or other means to an incurable patient, which leads to a mild and calm death upon the request of a patient who is aware of his actions and can control them and compulsory, which means causing light death by means of appropriate means and actions in the incurable patient, but by the decision of the family members, legal representatives or public institutions [17, p. 31].

In states that recognize euthanasia, particular attention is paid to the legal regulation of establishing the will of a person who agrees to euthanasia. In international law, the question remains whether the right to life also covers a person's obligation to live and whether a person, with the help of another person, can knowingly relinquish that right. The practice of international human rights bodies leaves this issue at the discretion of each state [11, p. 190].

Nowadays the euthanasia is legal in the Netherlands, Belgium, Ireland, Colombia, and Luxembourg. Assisted suicide is allowed in Switzerland, Germany, Japan, Albania, Canada, and several US states. Most clearly, the right to euthanasia is formulated in the Netherlands legislation and in Belgian and Swiss, there are clearly formulated and consistent wishes of the patient to die [17, p. 29-30].

Thus, the Netherlands is the first country that legalized euthanasia. In 1982, in this country was established the Euthanasia Commission, and on April 10, 2001, passed the Law on the Control of the End of Life at Will and Suicide Assistance. While the Netherlands still had age restrictions for children (12 to 16 years old), in 2002, Belgium passed a law that allowed euthanasia without age restrictions. Euthanasia for foreigners certified by a doctor is allowed in Switzerland. In November 2015, Germany also adopted a law on euthanasia [18].

Euthanasia does not mean a painless and swift death, because in only 16 out of 100 cases people died without agony, and the rest died from prolonged and greater suffering [18].

However, if the law of the state does not in any circumstances recognize the validity of euthanasia, then it (euthanasia) is recognized as a crime.

On June 5th, 2015, the ECHR delivered its judgment in the case of Lambert and Others v. France. The case was about end-of-life decision-making on behalf of a persistently incompetent patient (Vincent Lambert, a French citizen) who was in a vegetative state and had to be artificially fed and hydrated through a gastric tube. The controversy arose with respect to the removal of that tube, which would result in the patient's starvation, dehydration, and, ultimately, death: while some of the patients' relatives (parents, half-brother, and sister) wanted him to be kept fed and hydrated, his other relatives (wife and nephew) and caring physicians wanted the nutrition and hydration to be discontinued.

The controversy was litigated in the French courts, including the Administrative Court and the Conseil d'État. The courts came to drastically different conclusions: while the Administrative Court opined that the decision to withdraw artificial nutrition and hydration from $\mathrm{Mr}$. Lambert «had constituted a serious and manifestly unlawful breach of [his] right to life» the Conseil d'État held instead that the provision of the French Public Health Code authorizing physicians to withdraw and withhold «unreasonably obstina[te]» medical treatment «cannot be said to be incompatible with the requirements of Article 2 of the Convention [for the Protection of Human Rights and Fundamental Freedoms] ..., or with those of Article $8 \ldots »$. The Conseil d'État stressed that the law allowing the discontinuation of medical treatment provides for several procedural safeguards (reports about patient's medical condition, ascertaining his or her wishes about being kept alive while in a persistently unconscious state, consultations with patient's family members) and therefore meets the requirements of the Convention.

The ECHR, deciding on the application following the judgment of the Conseil d'État, focused its analysis on Article 2 of the Convention. In particular, the ECHR noted that the duty to protect human life, enshrined in Article 2 , consists of both positive and negative obligations of the States (that is, the obligations to «take appropriate steps to safeguard the lives of those within [the] jurisdiction [of the State]» and the obligations to «refrain from the «intentional» taking of life».

With respect to negative obligations, the ECHR observed that the «therapeutic abstention» (that is, withdrawal and withholding of medical treatment) lacks the intention to end patient's life - by contrast, a doctor discontinuing medical treatment from his or her patient merely intends to «allow death to resume its natural course and to relieve suffering» $[19 ; 20]$.

So, as to the judicial remedies that had been available to the applicants, the Court reached the conclusion that the present case had been the subject of an in-depth examination in the course of which all points of view could be expressed and that all aspects had been carefully considered, in the light of both a detailed expert medical report and general observations from the highest-ranking medical and ethical bodies. The Court concluded that the domestic authorities had complied with their positive obligations flowing from Article 2 of the Convention, in view of the margin of appreciation left to them in the present case, and that there would be no violation of Article 2 of the Convention in the event of implementation of the Conseil d'État judgment of 24 June 2014 [19].

The story of Mr. Lambert very much resembles the tragedy of Terri Schiavo in the United States, who was in a persistent vegetative state for more than ten years and was also artificially fed and hydrated. Her family also split with regard to her future: while the husband of Ms. Schiavo wanted the nutrition and hydration to be discontinued, her parents objected and wanted their daughter to be kept alive. The case arose a nation-wide controversy in the United States, culminating in a narrowly tailored bill approved by the Congress and signed by President Bush, and was ultimately decided in a federal court that approved the removal of the feeding tube [20]. 
On the mind of the teacher of bioethics, senior nurse of the palliative department in the Hospital of Metropolitan Andrey Sheptytsky Josaphat Drobik, from the point of view of moral theology of life is a gift of God and only He is the master of life and death. This is emphasized not only in Christianity but also in other religions. She noted that the more advances in euthanasia, the more the society departs from the moral standards of recognizing human life as the highest value on earth. It's like a slippery precarious slope on which we stand. But we must always remember that the question is not how we die, but how we live [18].

Abortion is an artificial abortion. There are debates and controversies around the world about the moral and legal status of abortion (the abortion controversy). The two main discussion groups call themselves «for choice» (with a clampdown on the right of women to choose) and "for life» (with a clampdown on the right of an unborn child to live). Each group, with different results, seeks to influence public opinion and seek legal support for its position. In some cases, the controversy was waged using violence. The legality of abortion varies from one country to another. For example, in Canada, abortions are available at the request of a pregnant woman, while abortions are prohibited in Ireland.

Globally, 25\% of pregnancies ended in abortion in 2010-2014, meaning 56 million induced abortions each year during this period. Between 1994 and 2014, the abortion rate declined markedly in developed regions, from 46 to 27 per 1000 women of childbearing age. In contrast, it remained roughly the same in developing regions (Guttmacher Institute, 2016). Despite variations in abortion legislation, most women in Western countries are granted full or partial self-determination up until the 12th or the 20th week of pregnancy [21].

There is a complete ban on abortion (except for life-saving women) in Afghanistan, Angola, Bangladesh, Venezuela, Guatemala, Honduras, Egypt, Indonesia, Iraq, Iran, Ireland, Yemen, Colombia, Lebanon and, Libya, Mauritania, Mauritania, Mauritania, UAE, Oman, Paraguay, Papua New Guinea, El Salvador, Syria, Chile, Philippines.

In England, India, Iceland, Luxembourg, Finland, Japan, abortions are allowed only on medical and socio-economic grounds and in cases of rape.

«Pre-requisite» abortions in the early stages of pregnancy are allowed in the Union of Independent States and Baltic states, Australia, Austria, Albania, Belgium, Bulgaria, Hungary, Vietnam, Germany, Greece, Denmark, Italy, Cambodia, Canada, China, Cuba, Mongolia, the Netherlands, Norway, Romania, Singapore, Slovakia, Tunisia, Turkey, France, Czech Republic, Sweden, South Africa [22, p. 101].

On May 14, 2019, Republican-controlled Alabama’s Senate of the United States passed the most violent abortion law in the US, which imposes a near-total ban on abortion. By law, abortion is a crime, even in the case of rape or incest (sexual intercourse between close blood relatives parents and children, siblings). Doctors who perform this procedure are in danger of being imprisoned for a period of 10 to 99 years. An abortion can be legal only if the mother's life is at risk or the fetus is not viable. However, on October 29, 2019, a US District Court judge blocked this controversial law [23].

If we turn to the experience of Ukraine, on the contrary, there is no ban on abortions. However, the legislation contains numerous rules relating to medical abortion practices aimed at protecting the life and health of women. According to Part 6 of Art. 281 of the Civil Code of Ukraine, artificial termination of pregnancy, if it does not exceed twelve weeks, can be carried out at the request of a woman. In cases prescribed by law, artificial termination of pregnancy may be carried out at a pregnancy of twelve to twenty-two weeks. The list of circumstances permitting termination of pregnancy after twelve weeks of pregnancy is established by law [24]. In Ukraine, it is also possible to terminate the life (death) of one of the fetuses during multiple pregnancies through medical intervention (selective fetocide) in order to preserve the life of another fetus.

Of course, illegal abortion carries criminal responsibility. International law does not contain provisions on the prohibition or validity of abortions. In universal or regional human rights treaties, states, by virtue of numerous religious and ideological factors, try to avoid as much as possible any specific answer to the question of how long a human embryo can be considered a human. For example, according to the Convention on the Rights of the Child of 20 November 1989, a child means every human being below the age of eighteen years unless, under the law applicable to the child, the majority is attained earlier (Art. 1) [25]. The Convention for the Protection of Human Rights and Fundamental Freedoms and the practice of its application relates to establishing a balance between the interests of pregnant women and the legitimate need to protect the embryo to the powers of the States Parties to this Convention [11, p. 191].

It should be noted that in giving women the right to decide abortion independently, most countries did not take into account their husband's right to paternity (one of the reproductive human rights). International non-governmental organizations are of the opinion that free abortion is a violation of the child's right to life. This position is confirmed by the point of view of modern embryology.

If we consider the realization of the right to reproductive choice (the right to abortion) globally, it should also be noted that in some countries there is a tendency to develop criminal businesses in the collection and distribution of abortion material. It is stem cell hunting - embryonic or fetal - that pushes «businessmen woe» to campaign for abortion among the population. The Church view of abortion is unchanged - it is the sin of child molestation.

Considering the life of a person, which may end with the assistance of medical staff (assisted suicide, euthanasia), one should also mention such a phenomenon as a medical error. Indeed, the death of a person is possible from the health care itself. Medical error has been defined as an unintended act (either of omission or commission) or one that does not achieve its intended outcome, the failure of a planned action to be completed as intended (an error 
of execution), the use of a wrong a plan to achieve a goal, or a deviation from the care process that may or may not cause harm to the patient. Patient harm from a medical error can occur at the individual or system level [26]. A medical error is legal, regardless of the consequences, with impunity. This is not a legal problem, but a medical one. Changing the concept of a medical error to a medical crime is unacceptable and leads to a destructive conflict of interest for patients and healthcare providers. Unlike in European countries, for example, statistics of medical errors are unfortunately not maintained in Ukraine. The nature of such errors in the world is different - due to the disorganization, poverty, unprofessionalism of physicians and the lack of general government management in this area.

In democratic countries, human life and health are recognized as the highest social value. That is why it is the direct responsibility of every state to ensure that effective jurisdictional mechanisms are in place to protect patients' rights, including those who have suffered from a medical error. The most effective jurisdictional mechanisms for protecting the patients' rights affected by a medical error are criminal law, civil law, and constitutional law mechanisms. At the same time, as international experience shows, there is also a need to create an effective system of non-jurisdictional mechanisms for the protection of patients' rights, which must include different insurance systems and alternative means of dispute settlement, in particular mediation [27, p. 2402].

The legal aspect of the human right to life requires the mention of such concepts as «necessary defense» and «extreme necessity» since everyone has the right to defend his or her life and health, life and health of others against unlawful encroachment. The necessary defense shall mean actions taken to defend the legally protected rights and interests of the defending person or another person, and also public interests and interests of the state, against a socially dangerous trespass, by inflicting such harm upon the trespasser as is necessary and sufficient in a given situation to immediately avert or stop the trespass, provided the limits of the necessary defense are not exceeded. Every person shall have the right to necessary defense notwithstanding any possibility to avoid a socially dangerous trespass or request assistance of other persons or authorities [28].

Infliction of harm to legally protected interests in circumstances of extreme necessity, that is to prevent an imminent danger to a person or legally protected rights of that person or other persons, and also public interests or interests of the state, shall not be a criminal offense, where the danger could not be prevented by other means and where the limits of extreme necessity were not exceeded [28].

Particular attention should be paid to the fact that international organizations have now begun to broaden the concept of the right to life, including not only the right to life as such. We can already see the weak so far, but the attempts to include in the understanding of this right the duty of the state to maintain and develop general conditions for a worthy life.

In view of this state of affairs and seeking to address the major problems related to the protection of the human rights to life, on 30 October 2018, the UN Human Rights Committee adopted General comment No. 36 on Article 6 of the International Covenant on Civil and Political Rights. Thus, the duty to protect life also implies that States parties should take appropriate measures to address the general conditions in society that may give rise to direct threats to life or prevent individuals from enjoying their right to life with dignity. These general conditions may include high levels of criminal and gun violence, pervasive traffic and industrial accidents, degradation of the environment, deprivation of land, territories and resources of indigenous peoples, the prevalence of life-threatening diseases, such as AIDS, tuberculosis or malaria, extensive substance abuse, widespread hunger and malnutrition and extreme poverty and homelessness. The measures called for addressing adequate conditions for protecting the right to life include, where necessary, measures designed to ensure access without delay by individuals to essential goods and services such as food, water, shelter, health-care, electricity and sanitation, and other measures designed to promote and facilitate adequate general conditions such as the bolstering of effective emergency health services, emergency response operations (including fire-fighters, ambulances and police forces) and social housing programs. States parties should also develop strategic plans for advancing the enjoyment of the right to life, which may comprise measures to fight the stigmatization associated with disabilities and diseases, including sexually transmitted diseases, which hamper access to medical care; detailed plans to promote education to non-violence; and campaigns for raising awareness of gender-based violence and harmful practices, and for improving access to medical examinations and treatments designed to reduce maternal and infant mortality. Furthermore, States parties should also develop, when necessary, contingency plans and disaster management plans designed to increase preparedness and address natural and man-made disasters, which may adversely affect enjoyment of the right to life, such as hurricanes, tsunamis, earthquakes, radio-active accidents and massive cyberattacks resulting in disruption of essential services [29, p. 6-7].

Everyone likes to live in a healthy environment which is a basic human necessity. A healthy environment is nature's gift. Air, water, and land are essential for all living beings. It has been recognized ever since Stockholm Declaration that both aspects of man's environment, the natural and man-made are essential to his well-being and to the enjoyment of basic human rights - even the right to life itself. The wholesome environment in the context of the right to life is a basic guarantee for the growth and development of individuals, society, and the nation itself. Human beings should be a central concern for sustainable development, and that they are entitled to a healthy and productive life in harmony with Nature [30, p. 79].

In order for a person to live a full life, he must be healthy. Healthy lifestyles are a lifestyle of every person aimed at preventing diseases and promoting health. Interesting is the Constitution of Hungary and Portugal. The Constitution 
of Hungary defines the right to the physical and mental health of a person. Hungary has enacted the Constitution on access to healthy food and drinking water, environmental protection, and the provision of systematic physical education. Sanitary education is prescribed as the basis of basic knowledge of citizens about the care of their health. The Portuguese Constitution defines the steps that the state must take to ensure the right to health care. These are areas of financial support for health care, medical services and the production of medicines and medical products. It also mentions the responsibility to protect and strengthen the right to health. Consequently, it establishes not only the right but also the responsibility of individuals for health care [31, p. 1338-1339].

The text of the European Convention on Human Rights does not contain a separate article defining the human right to health, but let's consider how then the ECHR resolves the issue of violating the right to health care. Let's begin with access to experimental treatment or a remedy in the case of Hristosov and others v. Bulgaria [32]. Ten applicants who had cancer were complaining that they were denied access to unauthorized experimental cancer therapies. In accordance with the law of Bulgaria, such a permit can be issued only if the medicine has been authorized in another country. While medications were allowed for "philanthropic use» in some countries, they were officially not allowed. Accordingly, the authorities of Bulgaria refused to issue a permit [31, p. 1340].

The ECHR ruled that Article 8 (right to respect for private and family life) of the European Convention on Human Rights had not been violated. Given the limitation of the patient's right to respect for private life, as provided for in Article 8 of the Convention, the tendency was to provide the possibility, in exceptional circumstances, of the use of unauthorized medicine in European countries. However, the court acknowledged that this consensus was based not on the consistent principles of the legislation of these countries and did not extend to the precise order governing the use of such drugs. The Court also held that Article 2 (right to life) and article 3 (prohibition of torture and inhuman or degrading treatment) of the Convention were not infringed in this case [31, p. 1340].

Case J.N. and others v. Italy [33] concerned the infection of the applicants or their relatives with the AIDS or hepatitis C. The interested parties suffered from hereditary disorders (thalassemia) and were infected during blood transfusion, conducted by the State Health Service. The applicants complained, in particular, that the authorities did not carry out the necessary screening to prevent infection. They also complained about shortcomings in the subsequent civil proceedings and the refusal to pay them compensation. In addition, they claimed to have been discriminated against in other groups of infected individuals. The Court held that Article 2 (right to life) of the Convention had not been violated in relation to the protection of life of applicants and their relatives, taking into account, that it had not been established that at the time of the proceedings the Ministry of Health was aware or one should be aware of the risk of transmission of ACID or hepatitis through blood transfusions, and it was impossible to determine from what moment the Ministry knew or should have been aware of the risk. The Court also held that there had been a violation of Article 2 of the Convention in respect of civil proceedings, given that the Italian judiciary, when considering disputed complaints under Article 2, was not able to provide an appropriate and prompt response in accordance with the procedural obligations of the State in accordance with the ruling. It has been found that there has been a violation of Article 14 (prohibition of discrimination), in conjunction with Article 2 of the Convention, by establishing that applicants, patients with thalassemia or their heirs were discriminated against in comparison with hemophiliac patients who had the opportunity to use the extrajudicial decision of the case proposed by the Ministry [31, p. 1340-1341].

Thus, the human right to health and the human right to life are very interrelated. In the case of the consequences of failure or inadequate provision of medical care are more substantial, reference should be made to the violation of Article 2 of the Convention - if the life of the person ended.

The right to life - broadly understood as a right to be free from deadly violence, maiming, torture, and starvation. The right to life is paramount. It is much more narrowly crafted than the right to many entitlements that improve life (e.g., health, housing, and education) but are not required for us to remain alive [34].

In addition, oncology remains the most painful problem in the world. Cancer ranks first among diseases that take a person's life.

For example, an analysis of the current situation in Ukraine makes it plausible that the lack of an effective early cancer prevention system due to the underfunding of the health care system and the lack of effective management in this area could be considered a violation of patients' rights. The right to health is violated by restriction of the right to early diagnosis in order to detect cancer in the early stages. Moreover, such restriction in many cases leads to violation of the right to life, taking into account the specificity of disease progress and the possibility of its treatment [35, p. 1109].

Unfortunately, the foregoing suggests that individual states do not pay sufficient attention to the need of effective public health policy. In today's world, there are objective prerequisites for changing the system of protection of patients' rights and, consequently, for changing views on health protection in general, especially in the part of functioning of diagnostic procedures system. However, in order to have an effective regulative impact on the content, the nature and intensity of activities in the field of health care there must be some kind of preliminary practice of state authorities in: studying the state and dynamics of these public relations; their legal assessment; prognostication of consequences from neglecting of processes in the field of providing the right to health; elucidation of resource and instrumental possibilities of the state concerning effective influence on protection of citizens' rights to health and life. Meanwhile, it must be admitted that the formation of a state policy on ensuring the rights 
of citizens to health and life, taking into account the various consequences of such a policy, cannot be narrowed down only to the proclamation of such rights, but also requires planning and development of relevant state programs. Analyzing the content of the declarative documents on the right to health and life, which is recognized as a typical form of state policy statement, it should be noted that their provisions should become a key source of law-making activity of the state in the relevant field of legislative regulation, and in the broader sense - the source of the organization of legal impact on health care relations. Failure by the state to provide the proper organization of health care through the establish ment of early diagnosis for cancer patients, considering wide incidence and mortal danger of cancer in case of late diagnosis, should be considered as a violation of human rights. The analysis of the practice of the ECHR makes it possible to state that such inaction of the state is an obvious violation of right to life (article 2), prohibition of tortures (article 3) and right to respect for private and family life (article 8) [35, p. 1112-1113].

Finally, it should be noted that we should agree with Dr. Mohd. Yousuf Bhat's and Dr. Syed Damsaz Ali Andrabi's opinion that the right to life is, therefore, the most fundamental of all rights, as it is the very core of humanity. It means a claim to so live that existence does not jeopardize the existence of others. It is not the only responsibility of individuals alone but State is a bigger partner in preserving the environment and in the realization of the right to life with human dignity. It is essential to create a shared international vision of long-term goals and to build the international frameworks that will help each country to play its part in meeting these common goals. There should be compatibility between the environment and economic development. Living standards beyond the basic minimum are sustainable only if consumption standards everywhere have regard for long term sustainability. Industrialized countries have an obligation to lead developing countries by shifting to sustainable development paths that would lead to a significant reduction in greenhouse gas emissions; promoting aggressive research on environmentally sustainable technologies; transferring such technologies to developing countries; and making large investments in climate-friendly technologies in developing countries. There should be a monitoring and reporting mechanism to provide a repository for information on compliance with universally accepted norms and a continuous and transparent effort [30, p. 84].

\section{CONCLUSIONS}

The right to life is a fundamental, inalienable human right that belongs to civil (personal) rights in the system of human and citizen rights and freedoms. This right consists of the following elements: the inalienability of the human right to life, the prohibition of arbitrary deprivation of life, and the right to protect one's life and that of others against unlawful encroachment. A person has the opportunity to manage his life at his own discretion, first of all, to use all legitimate means and resources for the prevention of pre- mature mortality, etc. The duty to protect the right to life, in particular, requires that states take appropriate measures to remedy the general conditions in society that may endanger lives or prevent persons from living a dignified life.

\section{REFERENCES}

1. Simić J. The protection of nasciturus within the civil law. Pravni zapisi. 2018; 9(2). doi: 10.5937/pravzap0-19193.

2. Universal Declaration of Human Rights of 10 December 1948. 2019. https://www.un.org/en/udhrbook/pdf/udhr_booklet_en_web.pdf.

3. International Covenant on Civil and Political Rights of 16 December 1966. 2019. https://www.ohchr.org/Documents/Professionallnterest/ccpr.pdf.

4. Convention for the Protection of Human Rights and Fundamental Freedoms of 04 November 1950. 2019. https://www.echr.coe.int/ Documents/Convention_ENG.pdf.

5. La Constitución de España del 27 de diciembre de 1978. 2019. http:// www.senado.es/web/conocersenado/normas/constitucion/index.html.

6. Konstytucja Rzeczypospolitej Polskiej z dnia 2 kwietnia 1997 r. 2019. https://www.sejm.gov.pl/prawo/konst/polski/kon1.htm.

7. Constituição da República Federativa do Brasil de 5 de outubro de 1988. 2019. http://www.russobras.com/doc/const_do_brasil_1988.pdf.

8. The Constitution of the United States of 17 September 1787. 2019. https://constitutionus.com/.

9. Konstytutsiia Ukrainy: vid 28 cherv. 1996r. No. 254k/96-VR [Constitution of Ukraine from June 28, 1996, NNo. 254k/96-VR]. 2019. http://zakon5. rada.gov.ua/laws/show/254\%D0\%BA/96-\%D0\%B2\%D1\%80. (in Ukrainiano.

10. U SSHA vidnovlyuyut' smertnu karu na federal'nomu rivni [In the US, the death penalty is being restored at the federal level]. 2019. https://www.bbc.com/ukrainian/news-49123818?ocid=socialflow_ facebook\&fbclid=IwAR2FSjolaPDy9gTgBszyXiJvXbU30NebyMZJQub_ orR2ciwXh8x5UDfb0jA. (in Ukrainian).

11. Tatsiy V.Ya., Petrishin O.V., Barabash Yu. G. et al. Konstytutsiya Ukrayiny. Naukovo-praktychnyy komentar [Constitution of Ukraine. Scientific and practical commentary]. Kh.: Pravo. 2011:1128. (in Ukrainian).

12. Rishennya Konstytutsiynoho Sudu Ukrayiny u spravi za konstytutsiynym podannyam 51 narodnoho deputata Ukrayiny shchodo vidpovidnosti Konstytutsiyi Ukrayiny (konstytutsiynosti) polozhen' statey 24, 58, 59, 60, 93, 190-1 Kryminal'noho kodeksu Ukrayiny v chastyni, shcho peredbachaye smertnu karu yak vyd pokarannya (sprava pro smertnu karu) vid 29 hrudnya 1999 roku № 11-rp/1999 [Judgment of the Constitutional Court of Ukraine in the case on the constitutional petition of 51 people's deputies of Ukraine on the constitutionality of the provisions of Articles 24, 58, 59, 60, 93, 190-1 of the Criminal Code of Ukraine in part, which provides for the death penalty as a form of punishment (Death Penalty Case) of 29 December 1999 № 11-rp/1999]. (in Ukrainian).

13. Rishennya Velykoyi palaty Konstytutsiynoho Sudu Ukrayiny u spravi za konstytutsiynym podannyam Upovnovazhenoho Verkhovnoyi Rady Ukrayiny z prav lyudyny shchodo vidpovidnosti Konstytutsiyi Ukrayiny (konstytutsiynosti) chastyny shostoyi statti 216 Kryminal'noho protsesual'noho kodeksu Ukrayiny vid 24 kvitnya 2018 roku №3-r/2018 [Judgment of the Grand Chamber of the Constitutional Court of Ukraine in the case on the constitutional petition of the Commissioner for Human Rights of the Verkhovna Rada of Ukraine on compliance with the Constitution of Ukraine (constitutionality) of part six of Article 216 of the Criminal Procedure Code of Ukraine of April 24, 2018 №3-r/2018]. 2019. (in Ukrainian). 
14. Postanova Plenumu Verkhovnoho Sudu Ukrayiny «Pro sudovu praktyku v spravakh pro zlochyny proty zhyttya ta zdorov'ya osoby» vid 7 lyutoho 2003 r. № 2 [Resolution of the Plenum of the Supreme Court of Ukraine «On Judicial Practice in Cases of Crimes against the Life and Health of a Person» of February 7, 2003 № 2]. 2019. (in Ukrainian).

15. Zakon Ukrainy «Pro Natsional'nu politsiyu»: vid 2 lyp. 2015 r. No. 580-VIII [Law of Ukraine «On the National Police» from July 2, 2015, 580-VIII]. (n.d.). zakon.rada.gov.ua. https://zakon.rada.gov.ua/laws/show/58019. 2019. (in Ukrainian).

16. D. Dudek. Samobójstwo. Źródło. 2019. https://www.mp.pl/pacjent/ psychiatria/choroby/76122,samobojstwo

17. Kaminska N.V., Nazarko Yu.V. Euthanasia and the human right to health protection. Naukovyy visnyk Natsional'noyi akademiyi vnutrishnikh sprav. Scientific Bulletin of the National Academy of Internal Affairs. 2017; 4:28-39.

18. Doktor moral'noho bohoslov"ya pro evtanaziyu: poshyreni mify, real'nist' ta suchasni vyklyky [Doctor of Moral Theology on Euthanasia: Common Myths, Reality, and Modern Challenges]. 2016. https:// ucu.edu.ua/news/doktor-moralnogo-bogoslov-ya-pro-evtanaziyuposhyreni-mify-realnist-ta-suchasni-vyklyky/. (in Ukrainian).

19. Case of Lambert and others v. France: judgment of European Court of Human Rights of 5 June 2015 (Application no. 46043/14). https://hudoc. echr.coe.int/fre\#\{\%22itemid\%22:[\%22001-155352\%22]\}. 2019.

20. From Therapeutic Abstention to the Right to Die? The Case of Lambert and Others v. France. Retrieved from https://strasbourgobservers. com/2015/07/06/from-therapeutic-abstention-to-the-right-to-diethe-case-of-lambert-and-others-v-france/ . 2019.

21. Kjelsvik M., Tveit Sekse R.J., Litleré Moi A., Aasen E.M. et al. Women's experiences when unsure about whether or not to have an abortion in the first trimester. Health Care for Women International 2018; 39 (7). doi: 10.1080/07399332.2018.1465945.

22. Bilousov V., Drobovych T., Melnyk P. Shtuchne pereryvannya vahitnosti: prohalyny v tsyvil'nomu zakonodavstvi [Artificial abortion: gaps in civil law]. Yurydychnyy visnyk, Legal Bulletin. 2016; 1 (38): 99-104. (in Ukrainian).

23. Alabama abortion law temporarily blocked by federal judge. 2019 . https://www.washingtonpost.com/health/2019/10/29/alabamaabortion-law-temporarily-blocked-by-federal-judge/.

24. Tsyvil'nyy kodeks Ukrayiny: vid 16 sichn. 2003 r. No. 435-IV [Civil Code of Ukraine from January 16, 2003 No. 435-IV]. (n.d.). zakon.rada.gov. ua. Retrieved from https://zakon.rada.gov.ua/laws/show/435-15. (in Ukrainian).

25. Convention on the Rights of the Child of 20 November 1989. 2019. https://www.ohchr.org/en/professionalinterest/pages/crc.aspx.

26. Makary M. A., Daniel M. Medical error - the third leading cause of death in the US. BMJ. 2016: 353. doi: 10.1136/bmj.i2139.

27. Yanovska 0., Horodovenko V., Bitsai A. Legal mechanisms of patient's rights protection. Wiad Lek . 2019; 72 (12) : 2399-2403.

28. Kryminal'nyy kodeks Ukrayiny: vid 5 kvitn. 2001 r. No. 2341-III [The Criminal Code of Ukraine from April 5, 2001 No. 2341-III]. (n.d.). zakon.rada.gov.ua. Retrieved from https://zakon.rada.gov.ua/laws/ show/2341-14. (in Ukrainian).
29. General comment No. 36 (2018) on article 6 of the International Covenant on Civil and Political Rights, on the right to life. Distr.: General 30 0ctober 2018. Adopted by the Committee at its 124th session (8 October to 2 November 2018). 2019:24.

30. Bhat M., Andrabi S.D.A. Right to life in context of clean environment: it's significance under various laws. IOSR Journal Of Humanities And Social Science (IOSR-JHSS). 2017; 22(5):79-85. doi: 10.9790/08372205107985.

31. Nazarko Yu., Iliashko 0., Kaminska N. Implementation of the right to health care in the countries of the European Union. Wiad Lek. 2019; 72(7): 1337-1342.

32. Case H. Bulgaria: judgment of European Court of Human Rights of 13 November 2012 . 2019. https://hudoc.echr. coe.int/ eng\#\{«itemid»:[«002-7298»]\}.

33. Case G. N. Italy: judgment of European Court of Human Rights of 01 December 2009 (Application no.43134/05). 2019.https://hudoc.echr.coe. int/eng-press\#\{\%22itemid\%22:[\%22003-2949481-3245864\%22]\}.

34. Etzioni A. Life: the most basic right. Journal of Human Rights. 2010; 9 (1). doi: 10.1080/14754830903530359

35. Tatsiy V., Gutorova N., Pashkov V. Legal Aspects of Cancer Diseases Prophylactics: Patient Rights Context. Wiad Lek 2017;120(6): 1108-1113.

\section{ORCID and contributionship:}

Anna V. Dzhuska: 0000-0003-4297-6792 A, B, D, E, F

Natalia V. Kaminska: 0000-0002-7239-8893 A, B, D, F

Zoryana M. Makarukha: 0000-0001-8252-6222 ${ }^{\text {B, D, E, F }}$

\section{Conflict of interest:}

The Authors declare no conflict of interest.

\section{CORRESPONDING AUTHOR \\ Anna V. Dzhuska}

V. I. Vernadsky Taurida National University

33 I. Kudri st., 01042 Kyiv, Ukraine

tel: +380639430461

e-mail: dzhuska@ukr.net

Received: 04.03 .2020

Accepted: 11.11 .2020

A - Work concept and design, B - Data collection and analysis, C - Responsibility for statistical analysis, D-Writing the article, $\mathbf{E}$-Critical review, $\mathbf{F}$ - Final approval of the article 